\title{
The Bayeux embroidery: a dust deposition assessment
}

\author{
Pauline Uring ${ }^{1 *} \mathbb{D}$, Anne Chabas ${ }^{1}$, Dominique De Reyer ${ }^{2}$, Lucile Gentaz ${ }^{1}$, Sylvain Triquet ${ }^{1}$, Cécile Mirande-Bret ${ }^{1}$ \\ and Stéphane Alfaro ${ }^{1}$
}

\begin{abstract}
Particulate matter in the showcase of the Bayeux embroidery was studied for 8 months in order to determine the conservation state of this precious and fragile work of art. Both the suspended and deposited particles were observed, analysed, and quantified. Microclimatic conditions were also monitored. This study presents different methods for the qualification (SEM-EDS and ion chromatography) and quantification (haze, surface coverage, deposition thickness, fibre concentration) of the deposition of particulate matter in such an environment. It allowed the evaluation of the hazard represented by particulate matter for the piece of art and the effectiveness of the measures taken to preserve it, namely air filtration in its over-pressured showcase. The results are very positive, since the PM concentration is very low (ISO 8 regarding the ISO 14644-1 norm) and dust deposition is still negligible after five and a half month.
\end{abstract}

Keywords: Particulate matter, Aerosols, Microclimate, Soiling, Deposition, Glass, Showcase

\section{Introduction \\ Context}

Many rare and precious objects are displayed in museums. To protect them and avoid their alteration, works of art are stored in controlled atmospheres where the concentration of outdoor pollutants is limited. However, indoor environments are also hazardous to cultural heritage materials and specific degradations can occur: numerous research projects are dedicated to the identification of the main causes of alteration.

The first studies about indoor air quality in museums pointed out ill-adapted microclimatic conditions as responsible for mould development or the enhancement of alteration processes [1]. This topic has been widely studied, which finally lead to a comprehensive understanding of these questions [2]. Curators now monitor temperature and relative humidity in museums [3] and follow norms and recommendations [4] to address this issue.

\footnotetext{
${ }^{*}$ Correspondence: pauline.uring@lisa.u-pec.fr

${ }^{1}$ Laboratoire Interuniversitaire des Systèmes Atmosphériques, UMR CNRS 7583, Université Paris Est Créteil et Université Paris Diderot, Institut Pierre Simon Laplace, 61, Avenue du Général de Gaulle, 94010 Créteil Cedex, France

Full list of author information is available at the end of the article
}

Volatile organic compounds (VOCs) have also been pointed out as being liable for the formation of efflorescence on artefacts and their rapid degradation [5], especially in showcases [6]. Materials that are to enter directly or indirectly in contact with pieces of art, such as cleaning products or construction materials [7], are now carefully chosen to limit the emission of hazardous VOCs.

Dust deposition is among the top subjects of concern to have attracted the conservation scientists' attention with increasing concern lately $[8,9]$. Indeed, particulate matter (PM) can be hazardous to fragile works of art in multiple ways. First of all, dust affects aesthetic quality through a phenomenon called soiling. It can be caused by soot and calcite particles [10] that settle in layers, thus hindering the reading of the artefact. Fine particles can penetrate through cracks $[4,11]$, coarse dust can cement under particular relative humidity (RH) conditions [12], making cleaning operations difficult. Furthermore, PM deposition causes and catalyses physical and chemical degradations: coarse dust abrades surfaces [4], sulphurrich particles discolour pigments or bloom on varnishes [13], alkaline aerosols speed up cellulose degradation [14]. Dust layers also form an attractive environment for mould and insects [15]. These conservation concerns are 
major ones and even more so as the artefact is precious and fragile.

To evaluate soiling risks in a specific environment, a comprehensive analysis of airborne pollutants must be produced. Both aerosols and deposited particulate matter (DPM) are to be characterized but studies that combine PM and DPM morphology, chemical composition and size remain rare and especially for the aerosol fine fraction (diameter $<1 \mu \mathrm{m}$ ). Our purpose is thus to document the environment of the showcase of the Bayeux embroidery (eleventh century), following a specific request from the museum and the Normandy DRAC (Regional Cultural Affairs Directorate). For the first time, dust deposition near this fragile work of art was assessed, pairing chemical analyses of PM and DPM with particle deposition rate evaluation in order to assess the effectiveness of protection means which were set up.

\section{The site}

The Bayeux embroidery is preserved on the ground floor of the Centre Guillaume-le-Conquérant, in Normandy, France. It is located $8 \mathrm{kms}$ from the seashore. Also called Queen Mathilda's embroidery, this piece of art is listed Memory of the World by UNESCO since 2007. It was made at the end of the eleventh century with wool yarns on a 70-m long flax fabric. It is nowadays presented behind a window in a reinforced concrete room with ventilation (G4 air filtration, slightly overpressured, humidifier) built in 1983.

\section{Methods}

\section{In-situ sampling analysis}

To collect deposited particles, two different methods were used. Old deposits, accumulated near the embroidery since the setup of the current showcase, were sucked up through a Millipore $0.4 \mu \mathrm{m}$ filter in a $35 \mathrm{~mm}$ Aerocheck ${ }^{\circledR}$ monitor cassette (surface studied: $160 \times 20 \mathrm{~cm}$ ). Ongoing deposition was collected on float Planilux ${ }^{\circledR} 6 \times 6 \times 0.2 \mathrm{~cm}$ glasses were displayed in the showcase for five and a half months, both horizontally and vertically. Because of its brittleness, any sampling or direct measurement necessitating contact with the embroidery is strictly forbidden and surrogate materials had to be used.

Air-suspended particles were also collected on filters through three specific filtration units, one for each of the analyses described in the next section. Sampling lasted 5 months where pumps were activated 2 min every hour at $10 \mathrm{~L} \mathrm{~min}^{-1}$.

The size distribution of the aerosol was measured between $10 \mathrm{~nm}$ and $40 \mu \mathrm{m}$ with a GRIMM $^{\circledR}$ Mini-WRAS, that classifies particles in 41 size channels thanks to the association of a NanoSizer GRIMM $^{\circledR}$ (electrometrical measure) and a GRIMM ${ }^{\circledR}$ (optical particle counter).
Microclimatic conditions were logged thanks to a VERITEQ ${ }^{\circledR}$ (SP-2000-20R-103 model) sensor. This device records both the temperature $\left( \pm 0.15{ }^{\circ} \mathrm{C}\right)$ and relative humidity $( \pm 2 \%)$ every hour.

\section{Analyses}

The particle deposited on glass coupons were characterized by the means of four parameters describing the optical impairment they induce. The rear face of the glass coupons was cleaned prior to these analyses.

1. Surface coverage was evaluated with Histolab Microvision ${ }^{\circledR}$ on 10 random observation fields (Leica Leitz Laborlux 12POLS microscope linked to a camera, with a total magnification of 526 , thus a $2.4280 \mathrm{~mm}^{2}$ surface per glass).

2. Deposited fibres, recognized as being the main factor leading to high surface coverage [16], were counted manually under a binocular magnifier Leica MZ10 (total magnification: $110 \times$ ).

3. Haze, commonly used in the glass industry as a soiling indicator [17], was measured thanks to a UV-visible spectrometer Perkin Elmer ${ }^{\circledR}$ Lambda 650S with a $60 \mathrm{~mm}$ integration sphere.

4. Deposition thickness was determined through profilometry, with a WYKO ${ }^{\circledR}$ NT1100 optical profiling system: the $\mathrm{Sz}$ parameter was assessed on 50 random fields per glass $(\times 50$ Mirau objective, $\times 0.5$ Field of View, $25.137 \times$ total magnification, VSI analysis mode with PSI High Mag filter).

In order to identify the main sources of PM, chemical analyses were also conducted on filters bearing samples of old deposits and of aerosols.

Scanning electron microscopy coupled with energy dispersive X-ray spectroscopy enabled the observation and elemental analysis of particles. Two devices were used, depending on the size of the observed particles: a Hitachi ${ }^{\circledR}$ TM3030 Benchtop SEM (up to $30.000 \times$ magnification) for coarse dust and a MERLIN ${ }^{\circledR}$ Carl Zeiss SEM (up to $10^{6} \times$ magnification) for fine and ultrafine particles. After a palladium metallization, particles in random fields (under a $5000 \times$ magnification) were counted, measured, analysed through EDX and sequenced according to their emission source. This method followed the procedure described in the literature $[18,19]$.

Ion chromatography allowed characterizing the soluble fraction of the aerosols. Filters were shaken for $30 \mathrm{~min}$ in ultra-pure water. The resulting solution was filtered $(0.2 \mu \mathrm{m}$, PTFE $)$ and an aliquot was used for cation and another for anion analysis with a Metrohm 850 Professional IC. Given the low concentrations involved, all these steps were conducted in an ISO 5 cleanroom. 


\section{Results and discussion}

\section{Microclimatic study}

Microclimatic conditions were monitored in the showcase from December 2015 to May 2016 (Fig. 1).

Though preset at a nominal value of $20^{\circ} \mathrm{C}$, the temperature varied between 18.4 and $21.7{ }^{\circ} \mathrm{C}$. A daily cycle $\left(2.5^{\circ} \mathrm{C}\right.$ range) is caused by the lights at the bottom of the display case, turned on each morning. It can be a stress for fragile textiles, but remains within the short fluctuation range of $\pm 2{ }^{\circ} \mathrm{C}$ recommended by ASHRAE [14].

Relative humidity remained stable around 45\% (varies from 39.9 to $49.4 \%$ ), responding to the usual requirements of a maximum short fluctuation of $\pm 5 \%$ in preventive conservation.

However, two specific periods show a different scheme.

First, from 2015 December 31st to 2016 January 29th, the museum was closed to the public and the embroidery was moved over a few metres to be specifically studied by curators. During this month, the daily increase in temperature nearly disappeared, which confirms that the lights are the origin of this issue.

End January, many people entered the usually empty local: 60 people were required to move the embroidery (on the 25th and on the 29th), researchers from different laboratories came to run analyses. This unusual frequentation caused $\mathrm{RH}$ and temperature fluctuations and everything went back to normal when the museum reopened.

From March 2nd to March 19th, a RH drop that cannot be explained by temperature variations occurred. This was likely due to an issue with the humidifying system, but the problem was gradually solved from March 14th.

Despite these exceptional periods, the hygrometric conditions are generally well controlled and remain within the limits recommended for sensitive materials.

\section{Particle concentration}

The particles size-resolved concentration was monitored in the lobby, the viewing area and the showcase in November 2015 (nearly empty museum) and July 2016 (crowded period). The size bins with a standard deviation over mean value higher than $100 \%$ were not considered: indeed, above $10 \mu \mathrm{m}$, only a few particles were detected, making the size bins between 10 and $40 \mu \mathrm{m}$ not significant.

Even if no specific fine particle filtration is used at the museum, particle concentration in the display case is low (Fig. 2). Though attendance is a known source of coarse

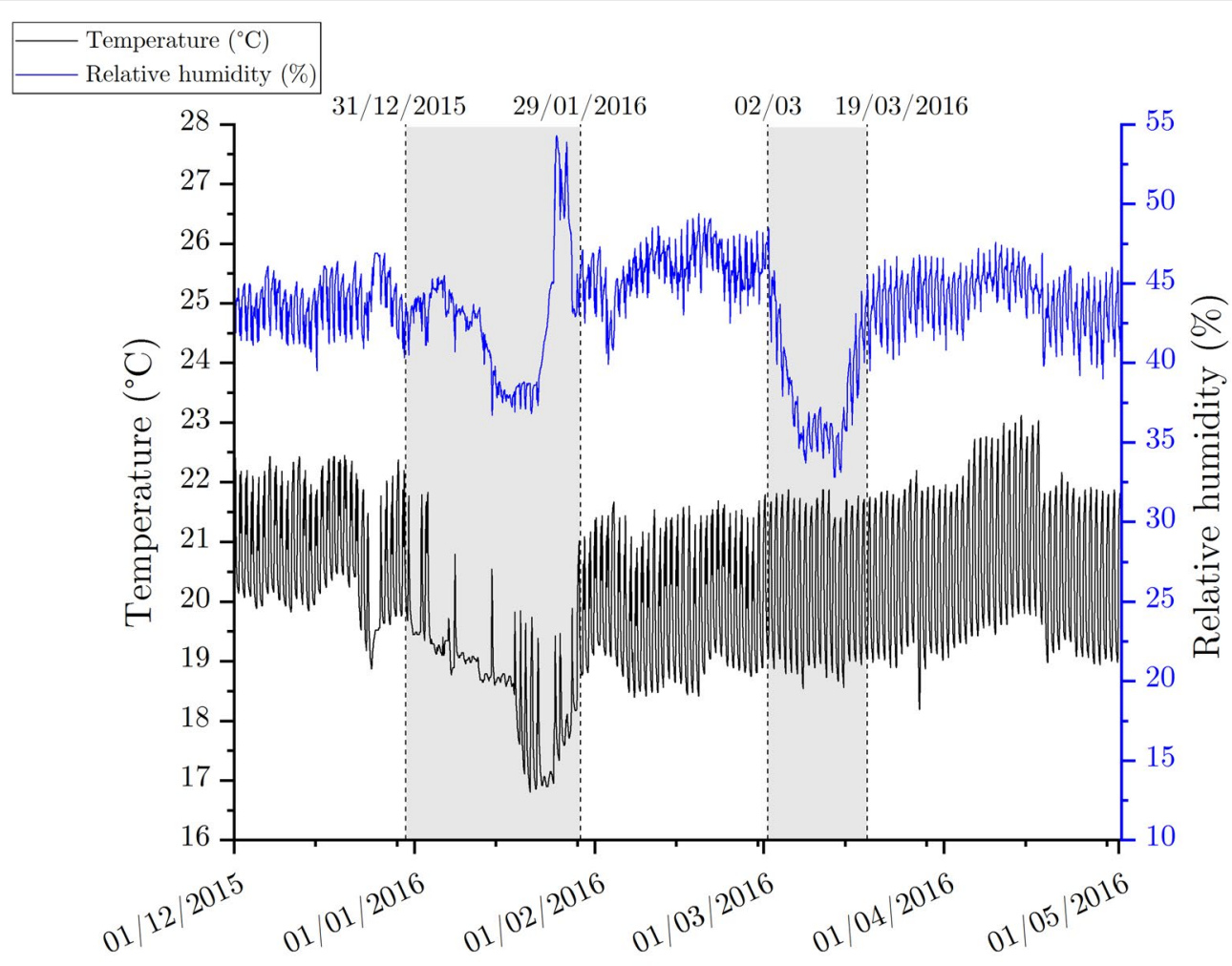

Date

Fig. 1 Temperature and relative humidity monitoring in Bayeux embroidery showcase 


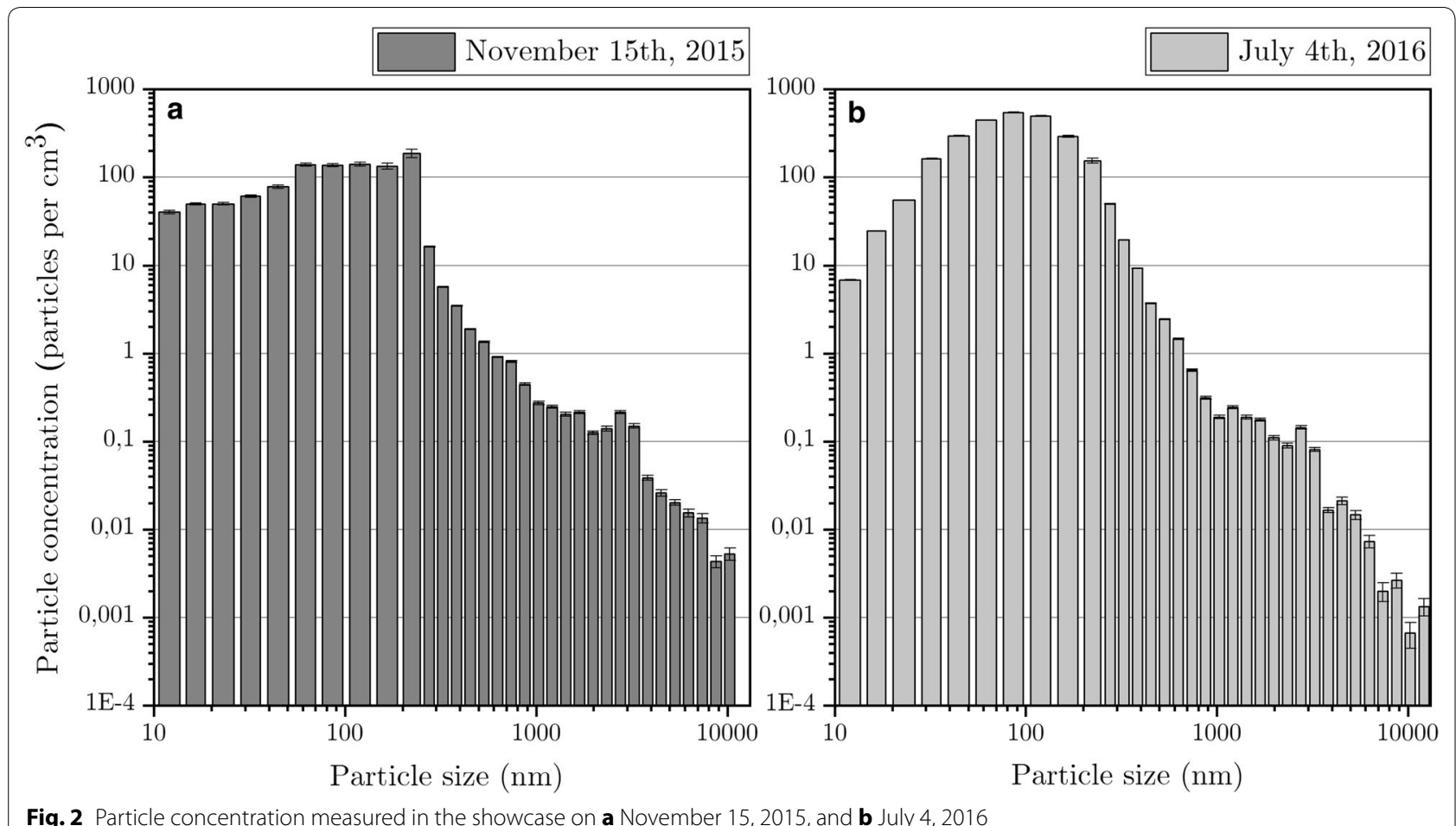

Fig. 2 Particle concentration measured in the showcase on a November 15, 2015, and b July 4, 2016

particles $[20,21]$, no significant effect on the concentration of these coarse particles was detected inside the display case. Indeed, particles larger than $1 \mu \mathrm{m}$ rather settle on horizontal surfaces [22] and thus hardly penetrate showcases. However, as compared to November a rise in the concentration of fine particles is noticeable in July. These fine particles are most likely (1) soot emitted by a denser traffic-an indirect consequence of the affluence-and (2) fine acidic and S-rich particles such as ammonium sulphate. These two type of particles are accountable for soiling [23] and cellulose degradation [9], respectively. Still, the air filtration unit and the window minimize the impact of the outside PM concentration and the environment matches that of an ISO 8 cleanroom in presence (Fig. 2b) or absence (Fig. 2a) of visitors.

For evaluating better the protection brought by the showcase, the abatements between the lobby and the viewing area as well as between the viewing area and the showcase were calculated (Fig. 3). From the museum reception to the viewing area, the reduction in particle concentration is limited (about a factor 1.4 for all particle sizes). This is due to the fact that the doors between the lobby and the exhibition area remain often open due to the constant visitor's flow, which prevents them from fulfilling their protective role. However, the particle concentration is much more significantly reduced between the viewing area and the showcase (open figures). Indeed, thanks to the showcase, the concentration of particles

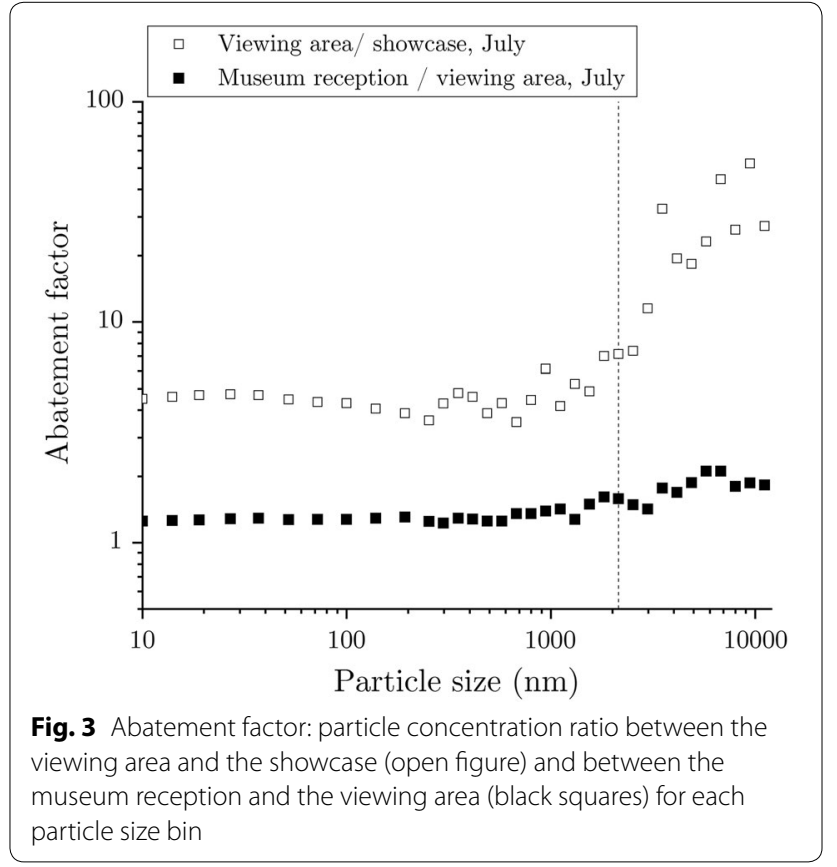

below $2 \mu \mathrm{m}$ is divided by 4 and by nearly 60 for particles above $2 \mu \mathrm{m}$. This shift in behaviour was confirmed by a Pettitt test [24] that detected a change point at $2 \mu \mathrm{m}$. This value matches the effectiveness of the G4 coarse particles air filter in use in the showcase. 
Concentrations both in the museum and in the showcase were compared to the literature: the latest values available were measured in two Greek museums and are reported in Table 1. Even if Bayeux has a slightly cleaner air, especially regarding $\mathrm{PM}_{2.5}$, the magnitudes of indoor $\mathrm{PM}_{10}$ and $\mathrm{PM}_{2.5}$ concentrations in these museums compare to that of Bayeux. However, when it comes to the showcase itself, the particle concentration reduction is more marked in Bayeux. Indeed, $\mathrm{PM}_{2.5}$ and $\mathrm{PM}_{10}$ are about 15-20 times lower than in these Greek display cases. This comparison with regular showcases not equipped with particle removal emphasizes the efficiency of filtration units such as the one used in Bayeux. Concerning fine particles $\left(\mathrm{PM}_{1}\right)$, for which no specific removal system is in place in Bayeux, the most relevant comparison is with the Neophytos Doukas Library because this is also a site located in a low polluted and marine area. Indoor concentrations are in the same order of magnitude (ca. 1000-1500 particles per $\mathrm{cm}^{3}$ ) in the two museums but the showcase of Bayeux shows an abatement when none is perceptible in Zagori.

Thus, the measures set for the preservation of the embroidery seem effective, given the strong reduction of particle concentration and the cleanroom environment in the showcase. However, despite the low particle concentration, chemical analysis are requested to identify particles and ensure their non-hazardousness towards the embroidery.

\section{Chemical analyses}

Particles' morphology, size and elemental composition were analysed through SEM-EDX, allowing to sort them by geochemical sources. Results are reported in Table 2 .

A third (33\%) of the observed aerosols are anthropogenic: soot, metallic scraps, Na-rich particles-probably nitronatrite $\left(\mathrm{NaNO}_{3}\right)$ - and mascagnite $\left(\left(\mathrm{NH}_{4}\right)_{2} \mathrm{SO}_{4}\right)$. Soot are carbonaceous particles emitted through combustion processes and their composition depends on the source: diesel soot has no specific marker, whereas K-rich soot indicates biomass combustion [26]. Moreover, their size depends on their age (from isolated soot to chainlike aggregate, from $100 \mathrm{~nm}$ to a few micrometres), making their removal by filtration less efficient than other particles.
Nitronatrite comes from the reaction between halite aerosols and atmospheric nitric acid [27]. Mascagnite (about $200 \mathrm{~nm}$-large bean-shaped particles) can be produced by gas-particle conversion from $\mathrm{SO}_{2}$ and $\mathrm{NH}_{3}$ [28]. As particles between 0.1 and $1 \mu \mathrm{m}$ easily penetrate buildings [29], an outdoor source of mascagnite is the most likely.

Marine aerosols represent about a quarter of the observed particles $(26.6 \%)$ : mostly halite $(\mathrm{NaCl})$ mixed with other salts [sylvite $(\mathrm{KCl})$, gypsum $\left(\mathrm{CaSO}_{4}\right)$, impurities], typically produced by seawater evaporation [30]. Indeed, Bayeux is $8 \mathrm{~km}$ away from the Channel and thus has an atmosphere loaded with marine salts able to penetrate inside the display case. Salts occasionally mix with terrigenous or organic particles, raising the global proportion of marine particles to about $30 \%$.

The proportions are quite different in the deposits: terrigenous particles, mostly silicate and clays-coming from soil erosion, represent more than half $(57.9 \%)$ the observed particles. Terrigenous particles were also found in the aerosol samples, but they were far smaller (about $1 \mu \mathrm{m}$ vs $5 \mu \mathrm{m}$ in the deposit) and in smaller proportions (about 13\%). This can be explained by the fact that terrigenous particles being often coarse, they settle fast and are over-represented in the deposit as compared to the airsuspended particles.

The same observation goes for other types of coarse particles or aggregates and explains that internal mixtures formed by the assemblage of different types of particles are more frequent in deposits.

The ion chromatography analysis of the soluble species present in the particulate matter (Fig. 4) confirmed the presence of ammonium sulphate (large proportion of $\mathrm{NH}_{4}{ }^{+}$and $\mathrm{SO}_{4}{ }^{2-}$ in the aerosols) as well as the marine influence $\left(\mathrm{Cl}^{-}\right.$anions and $\mathrm{Na}^{+}$cations in both the deposits and aerosols), already shown by SEM-EDS.

Deposits are characterized by the predominance of calcium cations, coming from both terrigenous (calcite) and marine (gypsum) particles. However, terrigenous particles are prevalent in deposits, as shown by SEM-EDS. Indeed, the ionic balance of the deposited particulate matter reveals a strong cation surplus: bicarbonate anions are missing from the analyses, disrupting the ionic balance.

Table 1 Particle concentration of various sites (average values)

\begin{tabular}{|c|c|c|c|c|}
\hline Site & Location & $\mathrm{PM}_{10}\left(\mu \mathrm{g} \mathrm{m}^{-3}\right)$ & $\mathrm{PM}_{2.5}\left(\mu \mathrm{g} \mathrm{m}^{-3}\right)$ & $\mathrm{PM}_{1}\left(\right.$ particles $\left.\mathrm{cm}^{-3}\right)$ \\
\hline \multirow[t]{2}{*}{ Bayeux } & Showcase & $2.2 \pm 0.9$ & $1.3 \pm 0.2$ & $300 \pm 80$ \\
\hline & Viewing area & $29 \pm 5$ & $7.3 \pm 0.8$ & $1000 \pm 500$ \\
\hline \multirow[t]{2}{*}{ Neophytos Doukas Library (Zagori) [25] } & Showcases & 60 & 20 & $1550 \pm 350$ \\
\hline & Indoor & 50 & 40 & $1600 \pm 360$ \\
\hline \multirow[t]{2}{*}{ Historical museum of Crete (Heraklion) [25] } & Showcases & 35 & 28 & Ca. 6000 \\
\hline & Indoor & 44 & 40 & Ca. 9500 \\
\hline
\end{tabular}


Table 2 Elemental analysis of deposited particles and aerosols within the display case

\begin{tabular}{|c|c|c|c|c|c|c|c|}
\hline \multirow[t]{2}{*}{ Origin } & \multirow[t]{2}{*}{ Elemental composition } & \multicolumn{3}{|l|}{ Aerosol } & \multicolumn{3}{|l|}{ Deposit } \\
\hline & & Number & $\%$ & Mean size $(\mu \mathrm{m})$ & Number & $\%$ & Mean size $(\mu \mathrm{m})$ \\
\hline Anthropogenic & & 31 & $33.0 \%$ & & 7 & $12.3 \%$ & \\
\hline Scrap metal fragments & $\mathrm{O}, \mathrm{Fe},(\mathrm{Al}, \mathrm{Si})$ & 2 & $2.1 \%$ & 2.2 & 5 & $8.8 \%$ & 1.8 \\
\hline Na-rich & $\mathrm{O}, \mathrm{Na}$ & 2 & $2.1 \%$ & 2.2 & 2 & $3.5 \%$ & 2.2 \\
\hline Soot & $C_{1}(S, K)$ & 20 & $21.3 \%$ & 0.8 & & & \\
\hline Mascagnite & $\mathrm{N}, \mathrm{S}, \mathrm{O}$ & 7 & $7.4 \%$ & 0.2 & & & \\
\hline Marine & & 25 & $26.6 \%$ & & 3 & $5.3 \%$ & \\
\hline Gypsum & $\mathrm{Ca}, \mathrm{S}, \mathrm{O}$ & 1 & $1.1 \%$ & 1.3 & 2 & $3.5 \%$ & 4.6 \\
\hline Halite + traces & $\mathrm{Na}, \mathrm{Cl},(\mathrm{Mg}, \mathrm{Si})$ & 23 & $24.5 \%$ & 0.8 & 1 & $1.8 \%$ & 2.2 \\
\hline Mix: halite, gypsum, sylvite & $\mathrm{Na}, \mathrm{Cl}, \mathrm{Ca}, \mathrm{K}, \mathrm{O}, \mathrm{S}$ & 1 & $1.1 \%$ & 1.8 & & & \\
\hline Terrigeneous & & 13 & $13.8 \%$ & & 33 & $57.9 \%$ & \\
\hline Clay & $\mathrm{Al}, \mathrm{Si}, \mathrm{O},(\mathrm{K}, \mathrm{Mg}, \mathrm{Fe}, \mathrm{S}, \mathrm{Na})$ & 9 & $9.6 \%$ & 1.3 & 9 & $15.8 \%$ & 5.5 \\
\hline Calcite & $\mathrm{Ca}, \mathrm{C}, \mathrm{O}$ & 1 & $1.1 \%$ & 0.6 & 3 & $5.3 \%$ & 2.7 \\
\hline Silicate & $\mathrm{Si}, \mathrm{O},(\mathrm{Na}, \mathrm{Ca}, \mathrm{K})$ & 2 & $2.1 \%$ & 0.7 & 19 & $33.3 \%$ & 4.6 \\
\hline Mix: calcite + clay & $\mathrm{Ca}, \mathrm{O}, \mathrm{C}, \mathrm{Al}, \mathrm{Si}$ & & & & 2 & $3.5 \%$ & 2.6 \\
\hline Mix: calcite + silicate & $\mathrm{Ca}, \mathrm{O}, \mathrm{C}, \mathrm{Si}$ & 1 & $1.1 \%$ & 2 & & & \\
\hline Mixtures & & 3 & $3.2 \%$ & & 12 & $21.1 \%$ & \\
\hline Marine-organic & $\mathrm{C}, \mathrm{Na}, \mathrm{Cl}$ & 1 & $1.1 \%$ & 0.5 & & & \\
\hline Marine-terrigeneous & $\mathrm{C}, \mathrm{O}, \mathrm{Na}, \mathrm{Cl}, \mathrm{Ca}, \mathrm{Al}, \mathrm{Si}, \mathrm{K}, \mathrm{S}, \mathrm{Mg}$ & 1 & $1.1 \%$ & 2.5 & 6 & $10.5 \%$ & 4.3 \\
\hline Marine-terrigeneous-organic & $\mathrm{C}, \mathrm{Na}, \mathrm{Cl}, \mathrm{Si}, \mathrm{O}, \mathrm{Mg}, \mathrm{Na}, \mathrm{Al},(\mathrm{S}, \mathrm{Ca})$ & 1 & $1.1 \%$ & 3.35 & & & \\
\hline Marine-anthropogenic & $\mathrm{O}, \mathrm{Al}, \mathrm{Fe},(\mathrm{Na}, \mathrm{Cl}, \mathrm{Ca}, \mathrm{Mg}, \mathrm{Si})$ & & & & 2 & $3.5 \%$ & 11.3 \\
\hline Terrigeneous-organic & $\mathrm{C}, \mathrm{Al}, \mathrm{Si}, \mathrm{O}, \mathrm{P}$ & & & & 3 & $5.3 \%$ & 5.5 \\
\hline Terrigeneous-anthropogenic & $\mathrm{C}, \mathrm{O}, \mathrm{Ca},(\mathrm{S})$ & & & & 1 & $1.8 \%$ & 6.0 \\
\hline Undetermined organic compounds & & 22 & $23.4 \%$ & & 2 & $3.5 \%$ & \\
\hline C-rich & $\mathrm{C}, \mathrm{O},(\mathrm{K}, \mathrm{S}, \mathrm{Na})$ & 22 & $23.4 \%$ & 0.35 & 2 & $3.5 \%$ & 9.4 \\
\hline Total & & 94 & $100 \%$ & & 57 & $100 \%$ & \\
\hline
\end{tabular}
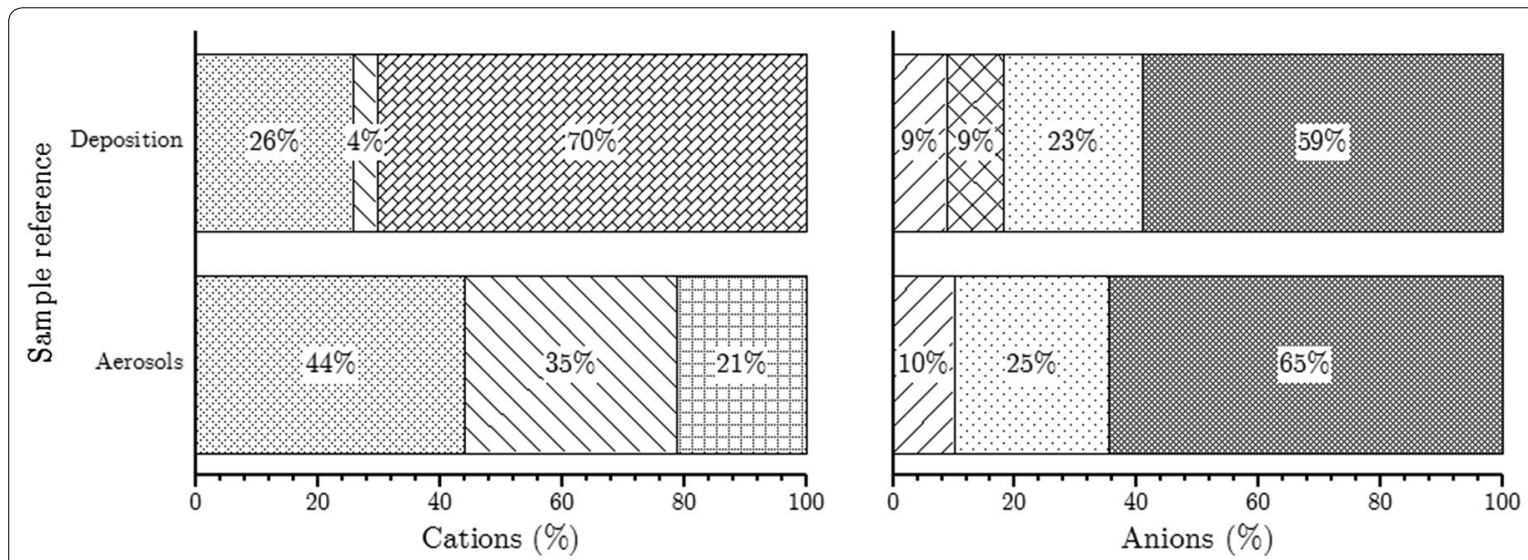

Sodium $\backslash \backslash$ Ammonium Passium Calcium

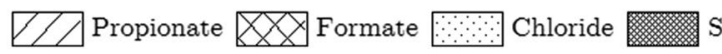

Sulfate

Fig. 4 Composition of the soluble fraction of the aerosols and deposits collected within the Bayeux embroidery showcase

Formate and propionate anions were found in low concentrations. Formate has most probably been emitted by the chipboards [31] at the back of the tapestry and subsequently adsorbed on the deposited particles, when propionate is a common Secondary organic aerosol (SOA) that forms in the atmosphere. However, no trace of acetate was detected: acetic acid, known to be a threat to organic collections [32], is thus not present here. 
The composition of both the atmosphere and the deposited particles in the showcase can be compared to the results of the analyses conducted in the Royal Museum of Fine Arts in Antwerp (Belgium) [33]. Like Bayeux, this museum is located near the Channel and therefore subject to marine influences. Regarding the bulk aerosol composition, similar particles were observed: small salts, some $\mathrm{Ca}$ - and $\mathrm{S}$-rich particles. However, less Fe-rich aerosols were detected in Bayeux. In the deposited particles, Ca-rich particles (terrigenous and marine) were observed in Bayeux (both in SEM and through ion chromatography), whereas it was noted that calcium had a rather low deposition rate in Antwerp.

\section{Particle deposition rate}

Particle deposition was evaluated after $5 \frac{1}{1 / 2}$ months on glass coupons displayed near the embroidery. The results are shown in Table 3.

First, giant particles $(>200 \mu \mathrm{m})$, mostly fibres, were studied and their surface concentration was calculated. As expected, the concentration of fibres is larger on the horizontal coupons than on the vertical ones because of the high settling velocity of these coarse particles. After being numbered, the origin of the fibres was determined by SEM observation: a few cotton and synthetic fibres were found that cannot come from the embroidery made of wool and flax. As the filtration unit is expected to remove giant particles from the ventilation system, these particles must have been brought during the moving of the embroidery between January 25th and 29th or during regular maintenance operations. They may also have penetrated the showcase despite the filters, but this phenomenon remains anecdotal.

All the measured parameters are characteristic of very clean surfaces: the haze remains below the value $(1 \%)$ commonly accepted as being the visual disturbance threshold in the glass industry [17] and the surface coverage as well as the thickness of the deposit are low. As expected, vertical coupons show less deposition than horizontal ones. The smallest difference between the horizontal and vertical exposures is obtained for the haze. According to the Mie theory, this parameter is essentially sensitive to the presence of fine (submicron) particles that scatter the UV and visible radiations efficiently. Because the deposition of such fine particles is driven more by diffusion than by gravitational settling [34], one does not expect them to deposit very differently on the vertical and horizontal coupons and, as a result, haze is less sensitive to the coupons orientation than the other parameters.

Regarding the Sz parameter (cf. Fig. 5), the deposit is more homogenous on the vertical sample. Indeed, only

Table 3 Measurements of soiling on glass coupons displayed for $5 \frac{1}{2}$ months in the showcase of Bayeux embroidery

\begin{tabular}{llllll}
\hline Coupon orientation & Mean $\mathbf{S z}(\boldsymbol{\mu m})$ & Median $\mathbf{S z}(\boldsymbol{\mu m})$ & Surface coverage (\%) & Fibres concentration $\left(\mathbf{f i b e r s} \mathbf{c m}^{\mathbf{- 2}}\right)$ & Haze $(\%)^{(\%)}$ \\
\hline Horizontal & $1.64 \pm 2.9$ & 0.39 & $0.45 \pm 0.05$ & $18.3 \pm 1.5$ & $0.49 \pm 0.10$ \\
Vertical & $0.28 \pm 0.03$ & 0.26 & $0.03 \pm 0.006$ & $1.2 \pm 0.2$ & $0.35 \pm 0.12$ \\
\hline
\end{tabular}

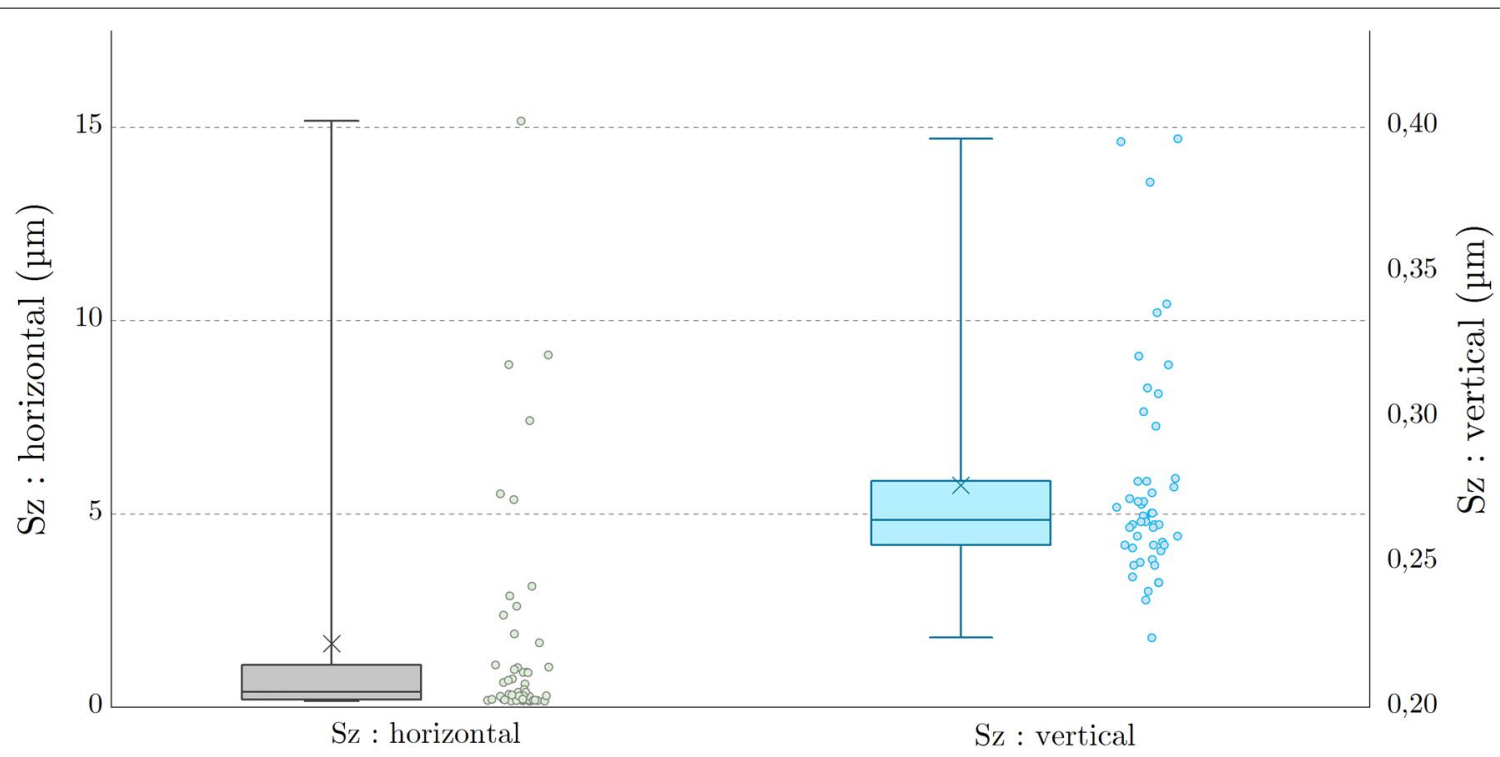

Fig. 5 Sz (maximum height, ISO 25178) on horizontal and vertical glass coupons 
small particles manage to adhere to the surface. Larger particles tend to sediment and are rather found on the horizontal coupon. Dust deposition on the latter is heterogeneous: most of the measurements are below $1 \mu \mathrm{m}$, but some larger particles are also measured, raising the mean $\mathrm{Sz}$ value.

According to all the evaluated parameters, after $5 \frac{1}{2}$ months exposure, dust deposition remains very low and dust accumulation is still at its origination, regardless of the orientation.

It is known that roughness has an impact on dust accumulation on a surface $[35,36]$. Thus, the deposition on the embroidery itself will be within the range defined by the upper (horizontal) and the lower (vertical glass) values measured on-site.

\section{Conclusion}

Preventive measures in place at the Bayeux Museum are effective regarding dust deposition. The showcase coupled with filtered air venting allow the atmosphere around the embroidery to be clean regarding particle concentration (ISO 8), even when the museum is crowded. However, despite the filtration, fine marine particle $($ ca. $0.5 \mu \mathrm{m})$ remain omnipresent. The relative humidity, well controlled, never reaches the $75 \%$ threshold corresponding to the deliquescence point of marine salts. These particles will thus be hardly harmful to the textile.

The main preservation concern, that's to say the daily temperature increase due to the heat produced by the lighting system, has been taken care of end 2016 to ensure a better conservation of the embroidery.

All the parameters used to assess the importance of soiling in the showcase of the Bayeux embroidery tend to show that regarding particulate matter, in-place protections-air filtration, specific concrete room, overpressure-are an example to follow in terms of preventive conservation.

\section{Authors' contributions}

AC, SA and DDR supervised the study. LG participated in sampling and on-site manipulations. ST and CM performed ion chromatography analyses. PU wrote the manuscript and performed aerosol and deposition characterization. $A C$ and SA revised the manuscript. All authors read and approved the final manuscript.

\section{Author details}

${ }^{1}$ Laboratoire Interuniversitaire des Systèmes Atmosphériques, UMR CNRS 7583, Université Paris Est Créteil et Université Paris Diderot, Institut Pierre Simon Laplace, 61, Avenue du Général de Gaulle, 94010 Créteil Cedex, France. ${ }^{2}$ Laboratoire de Recherche des Monuments Historiques, USR 3224, 29 Rue de Paris, 77420 Champs sur-Marne, France.

\section{Acknowledgements}

The authors would like to thank Cécile Binet and Kcénia Naoumenko from the DRAC Normandy for their financial support and heartwarming welcome, as well as Antoine Verney, Sylvette Lemagnen, Clémentine Berthelot and all the staff from the Bayeux Museum for making this study possible in excellent working conditions. Rémi Pires is also acknowledged for his SEM-EDX expertise.

\section{Competing interests}

The authors declare that they have no competing interests.

Availability of data and materials

Available upon request by the authors.

Ethics approval and consent to participate

Not applicable.

\section{Funding}

All the research was funded by the DRAC Normandy.

\section{Publisher's Note}

Springer Nature remains neutral with regard to jurisdictional claims in published maps and institutional affiliations.

Received: 14 February 2018 Accepted: 6 April 2018

Published online: 18 April 2018

\section{References}

1. Mecklenburg MF, Tumosa CS. Temperature and relative humidity effects on the mechanical and chemical stability of collections. Ashrae J. 1999:41:77-82.

2. Camuffo D. Microclimate for cultural heritage: conservation, restoration and maintenance of indoor and outdoor monuments. New York: Elsevier; 2014.

3. Camuffo D. Environmental monitoring in four European museums. Atmos Environ. 2001;35:S127-40.

4. Tétreault J. Polluants dans les musées et les archives: evaluation des risques, stratégies de contrôle et gestion de la préservation. Ottawa: Canadian Conservation Institute; 2003.

5. Grzywacz CM. Monitoring for gaseous pollutants in museums. Los Angeles: The Getty Conservation Institute; 2006.

6. Schieweck A, Salthammer T. Indoor air quality in passive-type museum showcases. J Cultur Herit. 2011;12:205-13.

7. Schieweck A, Salthammer T. Emissions from construction and decoration materials for museum showcases. Stud Conserv. 2009;54:218-35.

8. Grau-Bové J, Budič B, Cigić IK, Thickett D, Signorello S, Strlič M. The effect of particulate matter on paper degradation. Herit Sci. 2016;4:2.

9. Bartl B, Maskova L, Paulusova H, Smolik J, Bartlova L, Vodicka P. The effect of dust particles on cellulose degradation. Stud Conserv. 2016;61:203-8.

10. Godoi RHM, Potgieter-Vermaak S, Godoi AFL, Stranger M, Van Grieken R. Assessment of aerosol particles within the Rubens' House Museum in Antwerp, Belgium. X-Ray Spectrom. 2008;37:298-303.

11. Smolik J, Maskova L, Zikova N, Ondrackova L, Ondracek J. Deposition of suspended fine particulate matter in a library. Herit Sci. 2013;1:7.

12. Brimblecombe $P$, Thickett $D$, Yoon $Y H$. The cementation of coarse dust to indoor surfaces. J Cultur Herit. 2009;10:410-4.

13. Grau-Bové J, Strlic M. Fine particulate matter in indoor cultural heritage: a literature review. Herit Sci. 2013;1:8.

14. ASHRAE Handbook. HVAC applications. Atlanta: ASHRAE Inc; 2011.

15. Würtz H, Sigsgaard T, Valbjørn O, Doekes G, Meyer HW. The dustfall collector - a simple passive tool for long-term collection of airborne dust: a project under the Danish Mould in Buildings program (DAMIB). Indoor Air. 2005;15:33-40.

16. Yoon $\mathrm{YH}$, Brimblecombe P. The distribution of soiling by coarse patriculate matter in the museum environment. Indoor Air. 2001;11:232-40.

17. Lombardo T, lonescu A, Lefèvre RA, Chabas A, Ausset P, Cachier H. Soiling of silica-soda-lime float glass in urban environment: measurements and modelling. Atmos Environ. 2005;39:989-97.

18. Chabas A, Lefevre RA. Chemistry and microscopy of atmospheric particulates at Delos (Cyclades-Greece). Atmos Environ. 2000;34:225-38.

19. Chabas A, Lefevre RA. Soiling of soda-lime-silica float glass in the polluted atmosphere of Paris. Eur J Glass Sci Technol. 2002;39:79-83. 
20. Lloyd H, Lithgow K, Brimblecombe P, Yoon YH, Frame K, Knight B. The effects of visitor activity on dust in historic collections. Conservator. 2002;26:72-84.

21. Mašková L, Smolík J, Trávníčková T, Havlica J, Ondráčková L, Ondráček J. Contribution of visitors to the indoor PM in the National Library in Prague, Czech Republic. Aerosol Air Qual Res. 2016;16:1713-21.

22. Nazaroff WW. Indoor particle dynamics. Indoor Air. 2004;14:175-83.

23. Nazaroff WW, Salmon LG, Cass GR. Concentration and fate of airborne particles in museums. Environ Sci Technol. 1990;24:66-77.

24. Pohlert T. Trend: non-parametric trend tests and change-point detection. 2016. https://CRAN.R-project.org/package=trend. Accessed 29 Aug 2017.

25. Lazaridis M, Katsivela E, Kopanakis I, Raisi L, Panagiaris G. Indoor/outdoor particulate matter concentrations and microbial load in cultural heritage collections. Herit Sci. 2015;3:34.

26. Cachier H. Carbonaceous combustion aerosols. In: Harrison RM, Van Grieken R, editors. Atmospheric particle. Chichester: Wiley; 1998. p. 295-348.

27. Eriksson E. The yearly circulation of chloride and sulfur in nature; meteorological, geochemical and pedological implications. Part 2. Tellus. 1960;12:63-109.
28. Arrowsmith A, Hedley AB. The formation of ammonium sulphate particles by atmospheric reactions. Rev Port Quimica. 1975;17:168-73.

29. Grau-Bové J. Simulation of particulate matter deposition in indoor heritage environments. London: UCL; 2014.

30. Hardie LA, Eugster HP. Evaporation of seawater: calculated mineral sequences. Science. 1980;208:498-500.

31. Andersen I, Lundqvist G, Molhave L. Indoor air-pollution due to chipboard used as a construction material. Atmos Environ. 1975;9:1121-7.

32. Dupont A-L, Tétreault J. Cellulose degradation in an acetic acid environment. Stud Conserv. 2000;45:201-10.

33. Gysels K, Deutsch F, Grieken RV. Characterisation of particulate matter in the Royal Museum of Fine Arts, Antwerp, Belgium. Atmos Environ. 2002;36:4103-13.

34. Lai ACK, Nazaroff WW. Modelling indoor particle deposition from turbulent flow onto smooth surfaces. J Aerosol Sci. 2000;31:463-76.

35. Abadie M, Limam K, Allard F. Indoor particle pollution: effect of wall textures on particle deposition. Build Environ. 2001;36:821-7.

36. Lai ACK. Modeling indoor coarse particle deposition onto smooth and rough vertical surfaces. Atmos Environ. 2005;39:3823-30.

\section{Submit your manuscript to a SpringerOpen ${ }^{\odot}$ journal and benefit from:}

- Convenient online submission

- Rigorous peer review

- Open access: articles freely available online

- High visibility within the field

- Retaining the copyright to your article

Submit your next manuscript at $\boldsymbol{\nabla}$ springeropen.com 